UDC 658.512 .032

\author{
N. KosenKo, I. KADYKOVA, R. ARTIUKH
}

\title{
FORMALIZING THE PROBLEM OF A PROJECT TEAM BULDING BASED ON THE UTILITY THEORY
}

The subject matter of the article is mathematical models for solving particular problems of sorting out candidates for a project team. The aim is to create a region of compromises for a variety of particular criteria for selecting candidates and to develop an integral optimization function as a utility function for selecting preferred alternatives. The tasks are: developing the approximate area of compromises for solving single-criterion optimization problems; selecting the utility function of partial criteria; using general principles of utility theory application for solving personnel problems; sorting out the best option on the ground of multi-criteria evaluation and optimization methods; defining the degree of particular criteria importance; analyzing the peculiarities of multi-criteria assessment of problems in human resource management. The methods used are: multi-criteria assessment and optimization methods, utility function. The following results are obtained. The problem of estimating the relative importance of particular criteria in the utility function is considered. The procedure of determining the approximate region of compromises is described with account of a number of personal and psychological characteristics by successive solving single-criterion optimization problems for each particular criterion. The problem of developing the integral multi-criteria function for selecting preferred alternatives is considered. The peculiarities of using general principles of utility theory for personnel problems solving are analyzed. The function of multi-criteria optimization as a utility model for partial criteria is formulated. The general task of assessing and producing labour force with account of professional, personal and psychological properties of a candidate is formulated. Conclusions. The task of building a project team is considered in the article. The stages of team building are considered. The procedure for determining the approximate region of compromises is described with account of a number of personal and psychological characteristics by successive solving singlecriterion optimization problems for each particular criterion. The function of multi-criteria optimization is formulated as a utility model for partial criteria. The method for selecting and evaluating personnel for planned projects is suggested on the basis of the procedure for sorting out candidates for a new project team from the workers who were previously involved in similar projects.

Keywords: a project team building, utility function, multi-criteria optimization.

\section{Introduction}

Successful completion of a project is greatly determined by the way of its team building [1]. At the same time, the task of a project team building is considered as the most difficult for formalizing, since a variety of personal and psychological factors that are difficult to describe must be taken into account. At the same time, the success of the team's work greatly depends on the personal, business and psychological qualities of each individual employee $[2,3]$.

Personal and psychological characteristics are listed in each organization individually with account of specifics of its production activities and the nature of work on a newly planned project, the development prospects for the enterprise. A decision in these spheres is made by experts and a person who is responsible for making decisions (a decision maker) [8].

From a formal point of view, a project team building includes the following stages:

Step 1. Developing a variety of options for selecting candidates for the project;

Step 2. Working out the system for assessing the considered options (candidates);

Step 3. Defining the rule for choosing the best option or ordering preferred candidates.

Since each of the variants of the solution is characterized by a set of particular criteria, the system of assessment of the relative importance of particular criteria (the problem of estimating the significance of particular criteria) should be developed [8].

This article deals with the development of mathematical models for solving particular problems of a project team building; in particular with the creating the region of compromises for a number of particular criteria for selecting candidates and formulating an integral optimization function as a utility function, the aggregating value of a set of partial criteria.

\section{Creating the region of compromises}

Determining the approximate region of compromises $X^{P}$ the whole a set of points $x \in X^{C}$ is not excluded but only the solutions that determine the boundary of the region [4].

The condition for the correctness of such a procedure is the expression

$$
X^{C} \subset X^{P},
$$

that is, the complete inclusion of the exact region of compromises into the approximate one.

For determining $X^{P}$ the following procedure is used.

In the set of admissible solutions $X, n$ one-criteria optimization problems are consistently solved according to each particular criterion $k_{i}(x), i=\overline{1, n}$ :

$$
x_{i}^{0}=\arg \max _{x \in X} k_{i}(x) .
$$

For every solution $k_{i}(x)$ the value of all other partial criteria that is expressed as $k_{j}\left(x_{i}^{0}\right)=k_{j i}, j=\overline{1, n}$. is calculated. The obtained results are recorded in the matrix (2).

The matrix (2) is formed as follows: each line is composed of the values of the $i$-th partial criterion at the 
extremum points for all the particular criteria. Moreover, the extreme value of the criterion is achieved on the main diagonal.

\begin{tabular}{|c|c|c|c|c|}
\hline$k_{i}(x), i=\overline{1, n}$ & $k_{1}(x)$ & $k_{2}(x)$ & $\cdots$ & $k_{n}(x)$ \\
\hline$k_{1}(x)$ & $k_{11}$ & $k_{12}$ & $\cdots$ & $k_{1 n}$ \\
\hline$k_{2}(x)$ & $k_{21}$ & $k_{22}$ & $\cdots$ & $k_{21}$ \\
\hline$\ldots$ & $\cdots$ & $\cdots$ & $\cdots$ & $\cdots$ \\
\hline$k_{n}(x)$ & $k_{n 1}$ & $k_{n 2}$ & $\cdots$ & $k_{n n}$ \\
\hline
\end{tabular}

For example, the first line contains the criterion values $k_{1}(x)$ at points:

$$
k_{11}=k_{1}\left(x_{1}^{0}\right), k_{12}=k_{1}\left(x_{2}^{0}\right), \ldots k_{1 n}=k_{1 n}\left(x_{n}^{0}\right)
$$

where, $x_{1}^{0}, x_{2}^{0}, \ldots x_{n}^{0}$ is the solution that is extremal in accordance with $1,2 \ldots, n$-th criterion.

Thus, each line contains the values of the particular criterion $k_{i}(x)$ that varies from extreme $k_{i}(x)$ to the worst $k_{i H x}$. The sets of these values over all $i=\overline{1, n}$ are the boundaries of mapping the approximate region of compromises $X^{P}$ on the criteria space $K=\left\{k_{i}(x)\right\}$, $i=\overline{1, n}$.

The region $X^{P}$ in the space of particular criteria is given by constraints

$$
x \in X, \quad k_{i H x} \leq k_{i}(x) \leq k_{11}, \quad i=\overline{1, n} .
$$

The pattern corresponding to the constraints (3) of the approximate region of compromises for a convex region is shown in the figure 1.

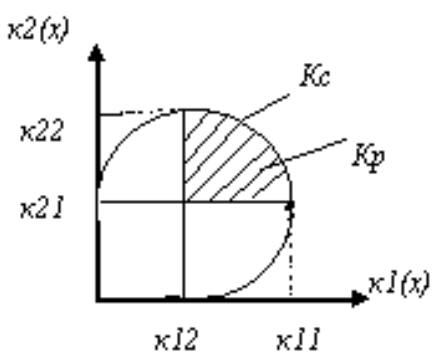

Fig.1. Approximate region of compromises $X^{P}$ on the convex set $X$

Such a basic assessment can be interpreted as the utility function of partial criteria $p\left[k_{i}(x)\right]$, in which $p: k_{i}(x) \rightarrow R^{1}, i=\overline{1, n}$. We can justify the choice of the pattern of the function $p$.

\section{The choice of utility function}

It is desirable that the utility function of the partial criteria be universal and well adapted to take into account the specific features of particular systems, their aims and criteria [5, 6].

To do this, the utility function must meet the following requirements:

- have a single interval of variation $[0,1]$;

- be dimensionless;

- be invariant to the pattern of the extremum of a particular criterion (minimum or maximum).

The latter means that, regardless of the type of extremum, its maximum value in the set must correspond to the maximum value (which is equal to 1 ), while the minimal value of the utility function (which is equal to 0 ) - to the worst one. In addition, the utility function of the partial criterion should enable both linear and non-linear non-decreasing convex upward or downward dependencies of the utility in the absolute value of the exponent.

All these conditions are met by the utility model of particular criteria [9].

$$
p\left[k_{i}^{H}(x)\right]=\left[\frac{k_{i}(x)-k^{H X}}{k^{H \wedge}-K_{i}^{H X}}\right]^{\alpha_{i}} .
$$

The theoretical basis of the engineering practice of developing generalized (complex) scalar estimates can be the utility principle. This principle is based on the assertion that there exists the quantitative estimate of the preference of solutions so that if solutions $x_{1} \succ x_{2}$, so $\left.\mathrm{P}\left(x_{1}\right)\right\rangle \mathrm{P}\left(x_{2}\right)$, where $\mathrm{P}\left(x_{1}\right)$ and $\mathrm{P}\left(x_{2}\right)$ are utility functions, which are a quantitative measure of the preference of the solution $x_{1}$ in relation to the decision $x_{2}$.

The peculiarities of using the general principles of application of the utility theory for solving personnel problems can be presented below by the following analysis.

The problem of choosing the best option $x^{0}$ can be solved on the basis of methods of multi-criteria estimation and optimization [7]. Then the pattern of the utility function can be represented as:

$$
\mathrm{P}(x)=F\left[\lambda_{i}, k_{i}(x)\right], i=\overline{1, n},
$$

where $k_{i}(x)$ is the $i$-th characteristics of a candidate; $\lambda_{i}$ is the coefficient of significance of $k_{i}$-th characteristic in a particular situation of choice; $F$ is a conversion operator (model structure);

The most famous and widely used pattern of representing the utility function is the additive one:

$$
\mathrm{P}(x)=\sum_{i=1}^{n} \lambda_{i} k_{i}(x) ; i=\overline{1, n} ;
$$

where $k_{i}(x)$ is a set of particular criteria (characteristics), considered candidates (options). In the formula (5) $\lambda_{i}$ is an isomorphism coefficient that takes into account the degree of relative importance of the particular criteria and leads to partial estimates $k_{i}(x)$ for a single dimension and change interval. Assessing the values of such 
coefficients is difficult, therefore in practice the more convenient additive form of the utility function is used:

$$
\mathrm{P}(x)=\sum_{i=1}^{n} a_{i} \kappa_{i}^{H}(x),
$$

where $a_{i}$ is relative dimensionless weighted coefficients satisfying conditions:

$$
0 \leq a_{i} \leq 1, \sum_{i=1}^{n} a_{i}=1,
$$

$k_{i}^{H}(x)$ is normalized values of particular criteria, (reduced to an isomorphic form in the model (4)).

In expression (6), all partial criteria are represented in isomorphic form $\left(k_{i}^{H}\right)$, and the main decision-making issue is a decision-maker's evaluation of the relative importance of the particular criteria and the form of their presentation. We can assume that the required information will be presented as dimensionless coefficients $a_{i}, i=\overline{1, n}$.

Determining the degree of importance of particular criteria is performed by a decision-maker or experts. More often, the information on weight coefficients can be presented in three forms:

1) deterministic;

2) probabilistic;

3) as a diffuse set.

The form of the presentation depends on the opinion of experts or the knowledge of decision-makers, and also to a large extent on the specifics of the considered object, the nature of its parameters, the methods of measuring them, and the time of observation (statistics, forecast).

The analysis of the peculiarities of multi-criterial estimation problems in the problems of human resource management enables focusing on the situations that are the most frequent in building project teams, the deterministic representation of the values of the importance coefficients $a_{i}$ of particular criteria $k_{i}(x)$.

For the situation where exact quantitative values of weight coefficients $a_{i}$ of particular criteria $k_{i}(x)$ are known the generalized utility of the alternative $x \in \mathrm{X}$ can be defined as the additive function:

$$
\mathrm{P}(x)=\sum_{i=1}^{n} a_{i} k_{i}^{H}(x), i=\overline{1, n}, \sum_{i=1}^{n} a_{i}=1 ;
$$

and the optimality principle

$$
x^{\circ}=\underset{x \in X}{\arg \max } \sum_{i=1}^{n} a_{i} k_{i}^{H}(x), i=\overline{1, n} \sum_{i=1}^{n} a_{i}=1 .
$$

In the expressions (7), (8) $k_{i}(x)$ is partial criteria for assessing the professional and personal qualities of candidates for the project. The coefficients of significance of particular criteria $a_{i}$, are determined by experts, proceeding from the features of works in the project and corporate traditions of an organization.
Another situation with a deterministic approach is formulated as follows. Coefficients $a_{i}$ are given quantitatively, however not exactly but as a certain interval $\left[a_{i} \min , a_{i} \max \right]$.

In this case the condition (7) is not performed, i.e. $\sum_{i=1}^{n} a_{i} \min \neq 1, \sum_{i=1}^{n} a_{i} \max \neq 1$. The preferred solution under these conditions may be obtained in two steps. In the beginning, the range of possible solutions is determined depending on the values $k_{i}(x)$ with changes of $\Delta a_{i}$, assuming $\sum_{i=1}^{n} a_{i}=1$, and $\mathrm{n}$ optimization problems are solved:

$$
\begin{gathered}
x_{i}^{\circ}=\arg \max \left[a_{i} \max k_{i}^{H}(x)+\sum_{i=1}^{n} a_{j} \mathrm{P}_{j}\left[\kappa_{j}(x)\right]\right] ; \\
\sum_{j=1}^{n} a_{j}=1-a_{i} \max , a_{j} \in\left[a_{j} \min , a_{j} \max \right] ; j=\overline{1, n}, i=\overline{1, n}, j \neq i,
\end{gathered}
$$

where $a_{i} \max$ is the maximum possible value of the $i$-th weighting factor.

According to the values $x_{i}^{\circ}, i=\overline{1, n}$ it is possible to calculate

$$
k_{\text {iHЛ }}=\max _{i} k_{i}\left(x_{i}^{\circ}\right) ; k_{i H X}=\min _{j} k_{i}\left(x_{j}^{\circ}\right) j=\overline{1, n}, i \neq j .
$$

Thus, the boundaries of the region are established, in which a compromise solution is determined at the second stage. The situation when experts cannot provide information on the coefficients $a_{i}$ is quite common in evaluating project personnel, but they can formulate the relative mutual importance of the evaluated criteria in the ranked series:

$$
k_{1}(x) \succ k_{2}(x) \succ \ldots \succ k_{n}(x) .
$$

In this situation, the part of applicants who corresponds to the most important criterion is sorted out from the total number of applicants for the project team $\mathrm{X}$ and the sequence of single-objective optimization tasks is solved:

$$
x_{1}^{\circ}=\underset{x \in X}{\arg \max _{i}}\left[k_{i}(x)\right] ; x_{2}^{\circ}=\underset{x \in X_{1}^{0}}{\arg \min _{i}}\left[k_{i}(x)\right] \text {, etc. }
$$

In other words, if the set consists of several candidates, then the problem of selecting candidates is solved according the second main criterion, etc.

The process of decision making lasts until a single candidate has been identified or the partial criteria have been exhausted.

\section{Conclusions}

The problem of assessing the relative importance of particular criteria in the utility function is considered. The importance of particular criteria is suggested to be 
presented as weight coefficients, which are determined by experts or decision-makers.

The procedure for determining the approximate region of compromises is described taking into account a multitude of personal and psychological characteristics by successive solving single-criterion optimization problems for each particular criterion.

The problem of developing an integral multi-criteria function for choosing preferred alternatives is considered. It is shown that the utility function is the most universal and well adapted for considering the peculiarities of specific systems, their aims and criteria. The features of using general principles of utility theory for the solution of personnel tasks are analyzed.

The function of multi-criteria optimization as the utility model of partial criteria is formulated. To create the integral criterion, the additive convolution is used.

The results of the work can be used to develop the mathematical and software of computerized control systems for the project team.

\section{References}

1. Sidorenko, A. V., Marchenko, E. M. (2016), "Personnel management tasks in the development and implementation of the project", Economics and management in the XXI century: development trends ["Zadachi upravlenija personalom pri razrabotke i realizacii proekta", Jekonomika i upravlenie v XXI veke: tendencii razvitija], No. 27, pp. 99-102.

2. Kosenko, N. V., Artyukh, R. V. (2016), "Automation methods of evaluation, selection and team building project on the basis of characteristics set", Systems of control, navigation and communication ["Avtomatyzatsiya metodiv otsinky, vidboru ta formuvannya komandy proektu na pidstavi mnozhyny kharakterystyk", Systemy upravlinnya, navihatsiyi ta zv"yazku], No. 2 (38), pp. 104-107.

3. Rozhkov, M., Cheung, B., Tsui, E. (2013), Project Context and its Effect on Individual Competencies and Project Team Performance, International Conference on Intellectual Capital and Knowledge Management and Organizational Learning, Academic Conferences International Limited, $602 \mathrm{p}$.

4. Baykasoglu, A., Dereli, T., Das, S. (2007) "Project team selection using fuzzy optimization approach", Cybernetics and Systems: An International Journal, Vol. 38, No. 2, pp. 155-185.

5. Fedorchenko, S. G., Dolgov, Ju. A., Kirsanova, A. V., Mencher, Je. M., Pomjan, S. V., Nizhegorodova, M. V., Andrianova, E. I., Koloskova, E. V., Kolegov, A. V., Bashkatov, A. M. Fedorchenko S.G. (ed.) (2011), Generalized utility function and its applications, publishing house of Transnistria University, Tiraspol, $196 \mathrm{p}$.

6. Horlachuk V., Yenal'yev M. (2013), "The development of the theory of expected utility", Economist ["Rozvytok teoriyi ochikuvanoyi korysnosti", Ekonomist], No. 3, pp. 49-50.

7. Mikoni, S. V. (2013), "Estimation of utility alternatives as the final stage of their multicriteria optimization" Proceedings of SPIIRAS ["Ocenivanie al'ternativ po poleznosti kak zavershajushhij jetap ih mnogokriterial'noj optimizacii", Trudy SPIIRAN], Vol. 8, No. 31, pp. 6-19.

8. Kosenko, N. V. (2012), "Formalized representation of the task of forming a project team", Systems of control, navigation and communication: scientific research journal Central Scientific - Research Institute of Navigation and management ["Formalizovannoe predstavlenie zadachi formirovanija proektnoj komandy", Systemy upravlinnya, navihatsiyi ta zv"yazku: zbirnyk naukovykh prats' Tsentral'noho naukovo - doslidnoho instytutu navihatsiyi i upravlinnya], Kyiv, No. 3 (23), pp. 138-141.

9. Dotsenko, N. V., Kosenko, N. V. (2012), "Comparative identification of the parameters of the multifactorial estimation model", Systems of control, navigation and communication: scientific research journal Central Scientific - Research Institute of Navigation and management ["Komparatornaja identifikacija parametrov modeli mnogofaktornogo ocenivanija", Systemy upravlinnya, navihatsiyi ta zv"yazku: zbirnyk naukovykh prats' Tsentral'noho naukovo - doslidnoho instytutu navihatsiyi i upravlinnya], Kyiv, Vol. 2, No. 1 (21), pp. 140-143.

\section{Відомості про авторів / Сведения об авторах / About the Authors}

Receive 08.06.2017

Косенко Наталія Вікторівна - кандидат технічних наук, Харківський національний університет міського господарства імені О. М. Бекетова, доцент кафедри управління проектами у міському господарстві і будівництві, м. Харків, Україна; e-mail: kosnatalja@ gmail.com; ORCID: 0000-0002-5942-3150.

Косенко Наталья Викторовна - кандидат технических наук, Харьковский национальный университет городского хозяйства имени А. Н. Бекетова, доцент кафедры управления проектами в городском хозяйстве и строительстве, г. Харьков, Украина; e-mail: kosnatalja@gmail.com; ORCID: 0000-0002-5942-3150.

Kosenko Nataliia - PhD (Engineering Sciences), O. M. Beketov Kharkiv National University of Urban Economy, Associate Professor at the Department of Project Management in Urban Economy and Construction, Kharkiv, Ukraine; e-mail: kosnatalja@gmail.com; ORCID: 0000-0002-5942-3150.

Кадикова Ірина Миколаївна - кандидат економічних наук, доцент, Харківський національний університет міського господарства імені О. М. Бекетова, доцент кафедри управління проектами у міському господарстві і будівництві, м. Харків, Україна; e-mail: irina.kadikova@kname.edu.ua; ORCID: 0000-0002-3189-7231.

Кадыкова Ирина Николаевна - кандидат экономических наук, доцент, Харьковский национальный университет городского хозяйства имени А. Н. Бекетова, доцент кафедры управления проектами в городском хозяйстве и строительстве, г. Харьков, Украина; e-mail: irina.kadikova@kname.edu.ua; ORCID: 0000-0002-3189-7231.

Kadykova Iryna - PhD (Economics Sciences), Associate Professor, O. M. Beketov Kharkiv National University of Urban Economy, Associate Professor at the Department of Project Management in Urban Economy and Construction, Kharkiv, Ukraine; e-mail: irina.kadikova@kname.edu.ua; ORCID: 0000-0002-3189-7231.

Артюх Роман Володимирович - кандидат технічних наук, ДП "Південний державний проектно-конструкторський та науково-дослідний інститут авіаційної промисловості", директор, м. Харків, Україна; e-mail: roman.artyuh77@gmail.com; ORCID: 0000-0002-5129-2221. 
Артюх Роман Владимирович - кандидат технических наук, ГП "Южный государственный проектно-конструкторский и научно-исследовательский институт авиационной промышленности", директор, г. Харьков, Украина; e-mail: roman.artyuh77@gmail.com; ORCID: 0000-0002-5129-2221.

Artiukh Roman - PhD (Engineering Sciences), SE "National Design \& Research Institute of Aerospace Industries", Director, Kharkiv, Ukraine; e-mail: roman.artyuh77@gmail.com; ORCID: 0000-0002-5129-2221.

\section{ФОРМАЛІЗАЦІЯ ЗАВДАННЯ ФОРМУВАННЯ КОМАНДИ ПРОЕКТУ НА ОСНОВІ ТЕОРІЇ КОРИСНОСТI}

Предметом вивчення в статті $є$ математичні моделі для вирішення окремих завдань підбору кандидатів при формуванні команди проекту. Мета - побудова області компромісів для безлічі окремих критеріїв підбору кандидатів та формування інтегральної оптимізаційної функції у вигляді функції корисності, для вибору кращих альтернатив. Завдання: побудова наближеної області компромісів для вирішення однокритеріальних оптимізаційних задач; вибір функції корисності часткових критеріїв; використання загальних принципів застосування теорії корисності для вирішення кадрових завдань; вибір найкращого варіанту, на основі методів багатокритеріального оцінювання і оптимізації; визначення ступеня важливості окремих критеріїв; аналіз особливостей завдань багатокритеріального оцінювання в задачах управління людськими ресурсами. Використовуваними методами $є$ методи багатокритеріального оцінювання і оптимізації, функція корисності. Отримані такі результати. Розглянуто задачу оцінки відносної важливості окремих критеріїв, що входять до функції корисності. Описана процедура визначення наближеної області компромісів з урахуванням безлічі особистісних психологічних характеристик шляхом послідовного вирішення однокритеріальних оптимізаційних задач по кожному окремому критерію. Розглянуто задачу формування інтегральної багатокритеріальної функції для вибору кращих альтернатив. Проаналізовано особливості використання загальних принципів теорії корисності для вирішення кадрових задач. Сформульовано функція багатокритеріальної оптимізації у вигляді моделі корисності часткових критеріїв. Сформульована загальна задача оцінювання та формування трудових ресурсів з урахуванням професійних і особистіснопсихологічних властивостей кандидата. Висновки. У статті розглянуто задачу формування команди проекту. Розглянуто етапи формування команди. Описана процедура визначення наближеної області компромісів із урахуванням безлічі особистісних і психологічних характеристик шляхом послідовного вирішення однокритеріальних оптимізаційних задач за кожним окремим критерієм. Сформульовано функція багатокритеріальної оптимізації у вигляді моделі корисності часткових критеріїв. Запропоновано метод підбору та оцінки кадрів для планованих проектів, в основу якого покладена процедура пошуку кандидатів до складу команди нового проекту зі складу виконавців аналогічних робіт в проектах минулих років.

Ключові слова: формування команди проекту, функція корисності, багатокритеріальна оптимізація.

\section{ФОРМАЛИЗАЦИЯ ЗАДАЧИ ФОРМИРОВАНИЯ КОМАНДЫ ПРОЕКТА НА ОСНОВЕ ТЕОРИИ ПОЛЕЗНОСТИ}

Предметом изучения в статье являются математические модели для решения частных задач подбора кандидатов при формировании команды проекта. Цель - построение области компромиссов для множества частных критериев подбора кандидатов и формирования интегральной оптимизационной функции в виде функции полезности, для выбора предпочтительных альтернатив. Задачи: построение приближенной области компромиссов для решения однокритериальных оптимизационных задач; выбор функции полезности частных критериев; использование общих принципов применения теории полезности для решения кадровых задач; выбор наилучшего варианта, на основе методов многокритериального оценивания и оптимизации; определение степени важности частных критериев; анализ особенностей задач многокритериального оценивания в задачах управления человеческими ресурсами. Используемыми методами являются методы многокритериального оценивания и оптимизации, функция полезности. Получены следующие результаты. Рассмотрена задача оценки относительной важности частных критериев, входящих в функцию полезности. Описана процедура определения приближенной области компромиссов с учётом множества личностных и психологических характеристик путём последовательного решения однокритериальных оптимизационных задач по каждому частному критерию. Рассмотрена задача формирования интегральной многокритериальной функции для выбора предпочтительных альтернатив. Проанализированы особенности использования общих принципов теории полезности для решения кадровых задач. Сформулирована функция многокритериальной оптимизации в виде модели полезности частных критериев. Сформулирована общая задача оценивания и формирования трудовых ресурсов с учетом профессиональных и личностнопсихологических свойств кандидата. Выводы. В статье рассмотрена задача формирования команды проекта. Рассмотрены этапы формирования команды. Описана процедура определения приближенной области компромиссов с учётом множества личностных и психологических характеристик путём последовательного решения однокритериальных оптимизационных задач по каждому частному критерию. Сформулирована функция многокритериальной оптимизации в виде модели полезности частных критериев. Предложен метод подбора и оценки кадров для планируемых проектов, в основу которого положена процедура поиска кандидатов в состав команды нового проекта из состава исполнителей аналогичных работ в проектах прошлых лет.

Ключевые слова: формирование команды проекта, функция полезности, многокритериальная оптимизация.

\section{Бібліографічні описи / Библиографические описания / Bibliographic descriptions}

Косенко Н. В., Кадикова І. М., Артюх Р. В. Формалізація завдання формування команди проекту на основі теорії корисності. Сучасний стан наукових досліджень та технологій в промисловості. Харків. 2017. № 1 (1). С. $53-57$.

Косенко Н. В., Кадыкова И. Н., Артюх Р. В. Формализация задачи формирования команды проекта на основе теории полезности. Сучасний стан наукових досліджень та технологій в промисловості. Харків. 2017. № 1 (1). С. $53-57$.

Kosenko N., Kadykova I., Artiukh R. Formalizing the problem of a project team bulding based on the utility theory. Innovative technologies and scientific solutions for industries. Kharkiv. 2017. No. 1 (1). P. 53-57. 